\title{
Literatura e diáspora: o caso dominicano nos Estados Unidos
}

Lívia Santos de Souza

Recebido em: 16 de março de 2019 Aceito em: 12 de abril de 2019
Lívia Santos de Souza é professora na Universidade Federal da Integração Latino-Americana (Unila) e desenvolve pesquisa na área de estudos caribenhos, com ênfase nas diásporas dominicana $e$ cubana nos Estados Unidos. Contato: liv42xu@gmail.com Brasil 
PALAVRAS-CHAVE: Literatura

dominicana; Diáspora; Literatura

latina nos Estados Unidos
KEYWORDS: Dominican

literature; Diaspora; Latin American literature in the United States.
Resumo: $\bigcirc$ presente artigo reflete sobre as relações entre literatura e diáspora, assumindo como eixo a produção artística da comunidade dominicana nos Estados Unidos. Inicialmente, é debatido o conceito de diáspora em suas differentes acepções e sua relação com a literatura. Em seguida, são debatidas as questões relativas à literatura dominicana elaborada nos Estados Unidos, com destaque para os principais autores e obras publicadas especialmente ao longo das últimas décadas. Conclui-se que, embora ainda bastante pouco explorada academicamente, a literatura de migração dominicana apresenta uma significativa riqueza formal e estética.

Abstract: This article reflects on the relations between literature and diaspora, taking as its axis the artistic production of the Dominican community in the United States. Initially, the concept of diaspora in its different meanings, and its relation with literature, is debated. Next, the issues related to the Dominican literature elaborated in the United States are discussed, highlighting the main authors and works published especially in the last decades. It is concluded that althoush still little explored academically, the literature of Dominican migration presents a significant formal and aesthetic wealth. 


\title{
INTRODUÇÃO: LITERATURA E DIÁSPORA
}

No início do século XXI, o mundo passa por um trânsito de informações e pessoas sem precedentes na história. Assim, compreender a lógica que rege esses deslocamentos tanto numerosos quanto complexos se torna uma tarefa absolutamente necessária para qualquer reflexão que busque melhor compreender o presente. Para tanto, faz sentido partir do próprio deslocamento enquanto conceito produtivo para a reflexão sobre a mobilidade e suas consequências no mundo contemporâneo.

\begin{abstract}
Entendido como vivência e prática dos sujeitos, o deslocamento é um conceito fundamental nos estudos sobre imaginário e memória cultural. Entendido como metodologia de trabalho, converte-se em paradigma fundamental para pensar processos culturais. Ou seja, o conceito abarca um amplo universo de significados e de relaçôes, sendo a remissão ao lugar, ou aos neologismos derivados da desconstrução da noção de lugar, o que articula essa ampla rede conceitual (Palmero González, 2010, 109).
\end{abstract}

Nesse contexto, ganharam significativo espaço termos como fronteira, margem, viagem, migração, crioulização, desarraigo, nomadismo, transculturação, hibridação e diáspora (Flores, 2008; Clifford, 1994), conceitos que muitas vezes se confundem e que, sem dúvida, requerem grande atenção metodológica. Para o presente artigo, interessa especialmente o último deles, diáspora, que, assim como seu derivado, sujeito diaspórico, passou por profundas transformaçóes desde seus primeiros usos. Por essa razão, nessa breve introdução pretendo me debruçar mais detidamente sobre o conceito, explicitando minha maneira de entender as diásporas 
contemporâneas e demonstrando como ele pode ser produtivo para uma reflexão sobre a literatura transnacional ligada à comunidade dominicana nos Estados Unidos (EUA).

Em seu ensaio "Diasporas", publicado em 1994, o antropólogo James Clifford se pergunta o que está em jogo nos mais diversos âmbitos quando o termo diáspora é empregado, evidenciando sua complexidade e a diversidade de sentidos que esse assumiu nas últimas décadas. Afirma o autor, citandoTötölian:

The term that once described Jewish, Greek, and Armenian dispersion now shares meanings with a larger semantic domain that includes words like immigrant, expatriate, refugee, guest-worker, exile community, ethnic community (Clifford, 1994, 203).

O termo que uma vez descreveu a dispersão de judeus, gregos e armênios agora partilha significados com um domínio semântico mais amplo que inclui palavras como imigrante, expatriado, refugiado, trabalhador temporário, comunidade de exílio, comunidade étnica.

Para Clifford (1994), embora situaçōes descritas como "de fronteira", como o fluxo de determinadas populaçóes que constantemente atravessam limites físicos arbitrários como a fronteira entre os Estados Unidos e o México, possam apresentar características diaspóricas, o movimento diaspórico pressupóe distâncias mais longas e exíguas perspectivas de retorno. Além disso, para ele, uma comunidade diaspórica deve compartilhar mais do que origem e destino, "a shared on going history of displacement, suffering, adaptation, or resistance" (Clifford, 1994, 306). 
Assim, se inicialmente o termo havia sido empregado para se referir ao deslocamento de um número específico de povos em um determinado momento histórico, na contemporaneidade a diáspora assume novas características e passa a englobar comunidades bastante diversas dos hebreus, gregos e armênios que tradicionalmente eram contemplados com seu uso.

Duany $(2010,271)$, refletindo também sobre a definição de diáspora na contemporaneidade, opta por associá-la a um termo caro para sua pesquisa sobre o Caribe hispânico: o transnacionalismo:

Por ahora, me parece suficiente señalar que las diásporas suelen conservar fuertes vinculos sociales, económicos, culturales, politicos y emocionales con sus lugares de origen. Las conexiones duraderas con una patria real o putativa mediante memorias, mitos y ritos colectivos constituyen uno de los criterios básicos para la mayoria de las definiciones de una diáspora (Brubaker, 2005; Cohen, 1997; Vertovec, 2009). Tanto el concepto de diáspora como el de transnacionalismo cuestionan la premisa común de que el estado nacional es la unidad - natural para conformar el espacio fisico y cultural en que se desenvuelven las personas.

Por agora me parece suficiente assinalar que as diásporas costumam conservar fortes vínculos sociais, econômicos, culturais, políticos e emocionais com seus lugares de origem. As conexóes duradouras com uma pátria real ou putativa mediante memórias, mitos e rituais coletivos constituem um dos critérios básicos para a maioria das definiçóes de uma diáspora. Tanto o conceito de diáspora quanto o de transnacionalismo questionam a premissa comum de que o estado nacional é a unidade 
natural para conformar o espaço físico e cultural em que se desenvolvem as pessoas.

Da imensa fortuna crítica que o termo diáspora apresenta na atualidade, gostaria de apresentar outro nome que fornece importantes contribuiçôes para a concepção de diáspora que interessa ao presente trabalho. Trata-se do ensaio "Diáspora, frontera e identidades transnacionales", publicado no livro Cartografias de la diáspora: identidades en cuestión (Cartographies of diaspora: contesting identities, no original) e escrito em 1996 pela socióloga de origem indiana radicada na Inglaterra Avtar Brah. Ao abordar a questão das diásporas contemporâneas levando em consideração uma série de questôes referentes ao gênero, a autora chama atenção, por exemplo, para o crescimento em número e em importância da quantidade de mulheres envolvidas em deslocamentos que podem ser considerados diaspóricos. Tal movimento de inclusão é fundamental para o estudo empreendido no presente trabalho, uma vez que as obras a serem analisadas refletem constantemente sobre conflitos de gênero em situações diaspóricas.

Outro aspecto que torna interessante a análise das diásporas a partir da perspectiva de Avtar Brah é seu cuidado com a definição do termo, um problema já assinalado no anteriormente citado artigo de James Clifford. Dessa forma, a autora afirma que concebe diáspora como:

Un conjunto de tecnologias de investigación que construyen la historia de las trayectorias de diferentes diásporas, y analizan sus relaciones a través de los campos de lo social, la subjetividad y la identidad. Expongo que el concepto de diáspora ofrece una crítica a los discursos que dan por sentados ciertos Orígenes 
inamovibles, mientras que tiene en cuenta un deseo de volver al hogar que no es lo mismo que el deseo de una "patria». Esta distinción es importante, especialmente porque no todas las diásporas mantienen una ideología de «retorno» (Brah, 2011, 204). ${ }^{1}$

Em "Diáspora, frontera e identidades transnacionales" há ainda um pertinente questionamento sobre como se constitui a voz coletiva da comunidade diaspórica. Um nosotros que se opóe ao otro representado pelo nativo. Nesse contexto, Brah problematiza o emprego do termo minoria, frequentemente empregado para se referir a grupos diaspóricos. A autora chama a atenção para o fato de que os discursos sobre minorias podem levar ao que ela denomina uma interpretação literal do termo, o que reduz as questôes de poder envolvidas na construção de minorias. Ao longo de todo o capítulo em que trabalha a diáspora nota-se a intensa preocupação de Brah em evidenciar as relaçóes de poder intrínsecas aos processos diaspóricos e desconstruir a aparente naturalidade de determinados discursos; essa talvez seja a sua maior contribuição para os estudos sobre o tema.

Um último autor fundamental para a presente reflexão sobre a diáspora é o intelectual de origem jamaicana Stuart Hall. Para Hall (2009), que no artigo "Pensando a diáspora: reflexóes sobre a terra no exterior" reflete

1 Um conjunto de tecnologias de investigação que constroem a história das trajetórias de diferentes diásporas, e analisam suas relaçôes através dos campos do social, da subjetividade e da identidade. Exponho que o conceito de diáspora oferece uma crítica aos discursos que dão por estabelecidas certas Origens inamovíveis, enquanto levam em consideração um desejo de voltar ao lar que não é o mesmo que o desejo de uma "pátria». Esta distinção é importante, especialmente porque nem todas as diásporas mantêm uma ideologia de «retorno» (Brah, 2011, 204, tradução nossa). 
sobre os movimentos diaspóricos protagonizados pelos povos caribenhos nas últimas décadas, o estudo de tal forma de deslocamento é fundamental por conta da "luz que ela é capaz de lançar sobre as complexidades, não simplesmente de se construir, mas de se imaginar a nação e a identidade caribenhas, numa era de globalização constante" (Hall, 2009, 25-26).

Nesse sentido, Hall (2009) chama atenção também para a capacidade de que povos em processos diaspóricos mantenham fortes laços com suas terras de origem, estabelecendo o que ele denomina famílias ampliadas. Outro termo empregado pelo autor com o objetivo de descrever essa característica é o de "identificação associativa", sentimento de pertencimento que não se enfraqueceria mesmo entre os que pertencem a segundas e até terceiras gerações.

Não se deve acreditar, no entanto, que a configuração da identidade cultural do sujeito diaspórico descrito por Hall (2009) se estabeleça unicamente com o país de origem. Hall (2009) aposta na multiplicidade da identidade em situaçóes diaspóricas, apontando que tais sujeitos constroem também laços com outros povos que encontram nos locais de destino e mesmo como grupos maiores de imigrantes. Um exemplo nesse sentido seria o caso de um imigrante proveniente do Caribe nos Estados Unidos que passa também a se identificar como latino. Esse processo de múltiplas associaçóes ocorre constantemente com escritores diaspóricos.

Hall $(2009$, 32) se volta, portanto, contra um "conceito fechado de diáspora que se apoia em uma concepção binária de diferença”. Para o autor, essa concepção que afirma uma oposição rígida entre um eu e um 
outro não é viável para as sincretizadas formas identitárias caribenhas. Hall $(2009,32)$ se volta entáo para a noçáo de différance como descrita por Derrida, uma concepção que rejeita binarismos e adota a existência de "places de passage" e significados que são posicionais, relacionais, sempre em deslize.

Tal afirmação tem relevantes impactos para a reflexão sobre a cultura caribenha levada a cabo por Hall (2009). Nesse contexto de fronteiras fluidas e desconstrução de dicotomias simplistas, fica claro que a cultura caribenha é marcada por impurezas e hibridaçôes, para utilizar termos empregados pelo autor, ou seja, ela é essencialmente diaspórica.

Hall (2009) enxerga na mistura proveniente do contato entre distintas diásporas e entre diásporas e povos receptores algo para além do negativo, um grande potencial criativo. Ganha destaque nesse contexto outro conceito caro para a compreensão desse processo: tradução, no sentido que Derrida deu ao termo. Para Hall (2009) essa tradução, que vai além da simples transposição de significados e que pressupóe a elaboração de novos sentidos, é o motor das manifestaçôes culturais e artísticas caribenhas de maior destaque.

Nas obras literárias provenientes das diásporas contemporâneas essa concepção de tradução se manifesta náo só na elaboração de versôes para as obras, mas também na própria elaboraçáo dos textos. Um texto escrito em um contexto de multipertencimento é muitas vezes um texto que precisa constantemente traduzir-se a si mesmo. Por essa razáo, em muitas obras com esse perfil, a voz narrativa atua não só como fio condutor da 
trama, mas como um mediador, alguém que transporta significados de uma realidade cultural a outra.

Para encerrar essa breve aproximação ao tema das diásporas contemporâneas, gostaria de conduzir um último retorno ao texto de Avtar Brah $(2011,214)$ sobre o tema:

Las diásporas, como experiencias históricas distintivas, a menudo son formaciones compuestas por muchos viajes a diferentes partes del globo, cada una con su propia historia, sus propias particularidades. Cada diáspora es un cruce de múltiples viajes; un texto de narraciones exclusivas y, quizás, incluso dispares.

Assim, as diásporas representam um tipo muito especial de texto, capaz de impulsionar a geraçáo de vários outros.

\section{LITERATURAS DA DIÁSPORA CARIBENHA HISPÂNICA NOS ESTADOS UNIDOS: O CASO DOMINICANO}

Como suas irmãs do Caribe hispânico, a literatura da diáspora dominicana também tem suas raízes no século XIX. Sobre essa chamada "literatura dominicana temprana en los Estados Unidos" merece destaque o ensaio "Before the diáspora: early dominican literature in the United States", de Silvio Torres-Saillant, publicado em 2000 como parte do volume Recovering the U.S. hispanic literary heritage. No texto, Torres-Saillant (2000) resgata registros da presença dominicana nos Estados Unidos desde o século XIX, passando pela importância da família Henriquez Ureña já no século XX, evidenciando como esses textos anteriores ao processo 
de transnacionalização podem ser vistos como precursores da chamada literatura dominicano-americana atual.

No entanto, do conjunto de literaturas diaspóricas caribenhas, a dominicana é a mais recente e também a mais escassamente estudada. A influência norte-americana no país, por outro lado, não é de maneira nenhuma recente; como aponta Duany (2010), as Antilhas hispânicas viram a dominaçấo econômica, militar e cultural espanhola de três séculos ser substituída pelo crescente imperialismo americano. Tanto as economias de Cuba quanto de Porto Rico e da República Dominicana giraram durante um longo período, mais precisamente o primeiro terço do século XX, em torno do fornecimento de açúcar para o mercado americano.

No caso dominicano, houve ainda uma ocupaçáo militar norteamericana entre os anos de 1916 e 1934 após sucessivas tentativas de anexação do país. Dessa forma, embora existam informaçôes sobre migração desse país para os EUA desde o século XIX, o movimento só pode ser considerado diaspórico a partir dos anos 1960 do século XX, quando o violento regime ditatorial levado a cabo por Rafael Leónidas Trujillo, que limitava fortemente a saída do país, teve fim. A literatura dominicana produzida nos Estados Unidos espelha essa circunstância, se levamos em consideração que são poucos os registros de obras com esse perfil durante o trujillato. O verbete da Encyclopedia of Hispanic-American Literature (2008) referente à literatura dominicana-americana menciona apenas dois autores identificados com esse período: André Requena, que em 1951 publicou o 
romance Cementerio sin cruces, e Angle Rafael Lamarches, responsável pelo volume de contos Los cuentos que Nueva York no sabe de 1951.

Outros livros publicados por dominicanos nos Estados Unidos nesse momento ainda anterior ao que definimos como diáspora no presente artigo podem ser identificados como literatura de exílio e são fortemente marcados pela oposição ao regime de Trujillo. Nesse sentido, merecem destaque ;Yo también acuso!, de Carmita Landestoy, título conhecido por ser um dos primeiros elaborado por uma mulher em enfretamento ao Trujillato, e as publicaçôes dos anos 1960 da folclorista Edna Garrido de Boggs.

Somando esse fator às condiçóes socioeconômicas do país na época e à aprovação do Immigration Act em 1965, que aumentou as cotas para imigração proveniente do Caribe, pode-se obter um panorama bastante claro das motivaçóes para a saída de uma parcela bastante significativa da população do país. Nova Iorque, Nova Iorque; Providence, Rhode Island; e Lawrence, Massachusetts, são algumas das cidades que concentram grande parte da comunidade dominicana estabelecida nos EUA. Regióes como Washington Heights na cidade de Nova Iorque são conhecidas por abrigar um grande número de moradores de origem dominicana e são, portanto, espaços em que a cultura dessa comunidade diaspórica se desenvolveu mais intensamente.

Cabe observar, no entanto, que embora os EUA sejam o principal destino dos movimentos migratórios da República Dominicana, existem também comunidades dominicanas instaladas em outros países e que 
também desenvolveram aspectos culturais próprios. No volume de 2013 Autores dominicanos de la diáspora: apuntes bio-bibliográficos (1902-2012) os autores Sarah Aponte e Franklin Gutiérrez inventariaram 229 escritores com publicações em países como Porto Rico, Alemanha, México, Venezuela e Argentina.

Estima-se que um em cada oito dominicanos viva nos Estados Unidos, taxa inferior aos outros países das Antilhas hispânicas, porém bastante significativa em 41 termos de crescimento recente. Desse grupo, em 2008, $41,9 \%$ havia nascido já em território americano, número que indica a força do desenvolvimento da comunidade já em território norte-americano. Outro aspecto a ser levado em consideração nesse sentido é a importância econômica da diáspora: as remessas financeiras dos Estados Unidos para a República Dominicana aumentaram cerca de 100 vezes nos últimos 40 anos e, mesmo que boa parte do montante náo seja devidamente processada pelas autoridades, os valores a que se tem acesso superam, por exemplo, a receita obtida com as exportaçóes no país (Duany, 2010).

Os dominicanos radicados nos Estados Unidos possuem ainda uma singular situação política com seu país de origem. Diferentemente do que ocorre com cubanos ou porto-riquenhos, por diferentes razóes, aos indivíduos de origem dominicana nascidos no Estado Unidos é concedida dupla nacionalidade pelo governo do país de origem. Dominicanos expatriados podem inclusive se candidatar a cargos políticos e votar remotamente em eleiçóes na República Dominicana. Como apontam Itzigsohn et al (1999), o congresso dominicano possuía, já no momento 
desse estudo, um representante em Nova Iorque. Tais características fortalecem o caráter transnacional da diáspora dominicana, uma vez que a manutenção dos vínculos entre os dois países é incentivada em nível institucional.

Tais características permitem a compreensão da cultura da diáspora dominicana como uma autêntica manifestação do transnacionalismo. Mais do que um processo de aculturação, como pressupunham teorias que apregoavam a ideia de melting pot, a diáspora hispano-caribenha como um todo é caracterizada por uma manutenção de determinados vínculos com a terra de origem, ao mesmo tempo em que são estabelecidos outros com o espaço que os sujeitos diaspóricos passam a ocupar, o repertório cultural desse indivíduo, dessa forma, é constituído por elementos de ambas as comunidades de que participa (Itzigsohn et al, 1999). Sobre essaquestão, afirma Duany $(2010,282)$ que:

el transnacionalismo desdibuja las fronteras, sin borrarlas por completo. Numerosos puertorriqueños, dominicanos y cubanos en Estados Unidos y Puerto Rico mantienen contactos sociales, políticos, económicos, culturales y emocionales con sus comunidades de origen. Muchos inmigrantes (y sus descendientes) llevan vidas bifocales, tendiendo puentes entre dos (o más) estados, mercados, culturas y lenguas. De ese modo, socavan los discursos dominantes sobre la nación, basados en la ecuación entre lugares de nacimiento y residencia, entre definiciones culturales y legales de la identidad y la ciudadania, entre fronteras $y$ límites. El cruce incesante de fronteras las hace más porosas, aun cuando los estados receptores insistan en fijar sus limites para protegerse de peligros externos. En pocas palabras, el transnacionalismo ha reconfigurado los bordes entre las Antillas hispánicas y Estados Unidos. 
Ainda sobre tal questão, cabe observar que a concepção da diáspora dominicana como um fenômeno transnacional é fundamental também para a reflexáo sobre o reposicionamento de questôes raciais nesse contexto de deslocamento, elemento de vital importância para a literatura que se constrói nesse espaço. Se, levando em consideração a composição étnica do Caribe, é possível em alguma medida que dominicanos não se identifiquem como negros quando na ilha, em território norte-americano é impossível se desvencilhar de categorias como latino, hispânico ou mesmo terceira raça (Méndez, 2008), rótulos que muitas vezes trazem consigo situações de discriminaçâo bastante análogas às vivenciadas por haitianos na República Dominicana, por exemplo.

Duany (2008), refletindo especialmente sobre jovens já nascidos no território americano, observa que existe uma relaçáo complexa com a herança africana. Por um lado, seu trabalho etnográfico em Quisqueya on the Hudson: the transnational identity of dominicans in Washington Heights (2008) revela que para esse grupo é importante a afirmaçáo de uma identidade dominicano-americana, que inclui processos de diferenciação da comunidade afro-americana como uma tentativa de aproximaçáo das outras comunidades latinas e caribenhas nos EUA. Por outro lado, esse mesmo grupo absorveu fortemente "consumer habits, speech patterns, dress, haircut, and fashions tyles" (Duany, 2008, 10) identificados com a cultura negra norte-americana. Essa aparente contradição identitária ganha importantes leituras literárias por parte de escritores que integram essa segunda geração, como é o caso de Junot Díaz. 
Porse tratar de um movimento diaspórico relativamente recente, os estudos sobre a comunidade dominicana nos Estados Unidos frequentemente traçam distinçôes entre as diferentes gerações que a compóem, afirmando a existência de uma segunda geração, com indivíduos que migraram ainda durante a infância ou que já nasceram em território americano, e de uma geração anterior, que chegou ao país em idade adulta. Para a chamada primeira geração, a terra natal ainda é descrita como "mi pais” em oposição aos Estados Unidos, frequentemente descritos como "este pais" (Duany, 2008, 3). Essa percepção tão marcada de lá e aqui parece perder força quando se trata das geraçóes mais recentes.

Dessa forma, embora tenha registros anteriores, como revela também a antologia Literatura dominicana en los Estados Unidos: presencia temprana, 1900-1950, organizada por Daisy Cocco de Filippis em 2001, dedicada a dar visibilidade a textos com esse perfil produzidos na primeira metade do século XX, e volumes como o já citado Autores dominicanos de la diáspora: apuntes biobibliográficos (1902-2012), apenas nos anos 1980, entretanto, a produção literária dominicana nos Estados Unidos passa a ser academicamente estudada com maior frequência e ganha maior atenção, tanto da crítica quanto do mercado editorial em geral. Um quadro elaborado pelos autores desse livro demonstra que o número de publicações de autores de origem dominicana no exterior mais do que triplica se comparados os períodos 1971-1980 e 1981-1990, cresce substancialmente até os anos 2000 e ainda mais intensamente entre 2001 e 2012. 
Outro elemento que merece atenção sobre o tema é que o fenômeno da diáspora, apesar dos supracitados vínculos mantidos entre os dois espaços, provocou também uma controversa divisão nos discursos sobre a literatura dominicana. Contraditoriamente, já que parece haver uma clara manutenção dessa configuração identitária em diversos âmbitos, no plano literário/cultural a segregação persiste, e passou-se a falar nas últimas décadas em literatura dominicana produzida na República Dominicana em oposiçáo a uma literatura dominicana produzida nos Estados Unidos.

É comum encontrar na literatura especializada referências à "literatura dominicana da ilha", fato que evidencia a complexidade do tema. Tal processo parece ser uma constante nas literaturas da diáspora caribenha, Jorge Duany (2007), antropólogo porto-riquenho, descreve uma situação bastante semelhante em relação a seu país de origem; a existência de uma literatura porto-riquenha da ilha em oposição à outra produzida fora dela, ressaltando a ausência de nomes da literatura diaspórica do país no currículo escolar da ilha. Em Cuba observa-se o mesmo movimento. Existe uma nítida distinção entre a literatura produzida na ilha e a produzida fora dela, com muita resistência ao reconhecimento da existência de uma produçáo cubana escrita em inglês.

Embora venha perdendo força na atualidade, são cada vez mais comuns críticos que se recusam a operar essa divisão. Tal fenômeno deixa claro que para 45 determinados setores da crítica literária contemporânea, elementos territoriais continuam sendo excessivamente importantes na configuraçáo do cânone e das literaturas nacionais. 
William Luis (2006), no capítulo dedicado às literaturas hispanocaribenhas produzidas nos Estados Unidos na Historia de la literatura hispanoamericana organizada por Roberto González Echevarría e Enrique Pupo-Walker, fala na emergência da literatura vinculada a essa comunidade como estreitamente identificada com a poesia. De fato, essa afirmação parece se confirmar também nos estudos de Acosta e Gutiérrez (2005), que identificam um número substancialmente maior de conjuntos de poemas e livros de ensaio em relação à publicação de volumes de contos e romances.

Entretanto, nas últimas décadas diversos nomes surgiram também relacionados à prosa. Pode-se identificar, nesse grupo, a maciça presença de escritores que migraram ainda durante a infância ou que em alguns casos são já nascidos nos Estados Unidos, traço que os diferencia marcadamente dos poetas descritos por William Luis, em grande parte expatriados já em sua vida adulta. Esse é inclusive o critério de classificação adotado por Luis, que separa a literatura da diáspora hispano-caribenha em um grupo formado por escritores cuja formaçáo inicial se deu em seus países de origem, em oposiçáo a um segundo grupo nascido e criado já nos Estados Unidos.

Um dos elementos mais influentes relacionado a esse dado sociológico sobre os narradores da diáspora dominicana é a escolha da língua literária. Jesús J. Barquet $(2011,1)$, refletindo sobre essa questão, afirma que existe uma tendência para autores que chegaram "niños, o casi niños" nos Estados Unidos a adotar o inglês como língua literária, elemento que obedeceria 
a uma série de demandas sociais e mercadológicas em relação à produção literária.

Sobre esse tema, Margarita Mateo Palmer (1993) chama atenção para o fato de a literatura caribenha ser naturalmente plurilíngue e que a escolha da língua literária é uma questão mesmo para muitos escritores radicados em seus países de origem. Nesse sentido, a opção por formas linguísticas hibridizadas como o francês influenciado pelas distintas línguas crioulas ou pelo inglês, que se contamina com traços do espanhol, não seria uma forma menor de expressão, mas sim um recursoque permite explorar a riqueza e a complexidade das experiências diaspóricas. A mescla ocasionada pelo contato entre diferentes culturas, nesse contexto, é uma marca da riqueza dessa produção literária e não um recurso que a tornaria menor.

É inegável, no entanto, que escritores identificados com as comunidades latino-americanas nos Estados Unidos que escrevem em inglês acabam por ter uma aceitação significativamente mais ampla nesse país. Isso pode ser explicado pela grande resistência do mercado consumidor editorial norte-americano frente a livros reduzidos de forma geral. Venuti (1998) afirma que apenas 10\% dos livros que circulam no país são traduçóes. Escrever em um inglês hibridizado, incorporando elementos da língua espanhola, portanto, pode se tornar uma estratégia de inserção no campo literário norte-americano que incorpora a lógica das formações identitárias transnacionais.

Contribui ainda para essa separação entre literatura da ilha e literatura diaspórica o fato de que a circulação de textos dominicano-americanos 
na República Dominicana é bastante reduzida. No entanto, como aponta Ostman (2017), os textos da diáspora dominicana são relevantes testemunhos do que seria a dominicanidade contemporaneamente e devem, portanto, ser lidos de forma integrada ao que se produz na ilha.

O mesmo poderia se afirmar sobre a produção crítica elaborada por intelectuais diaspóricos. Trabalhos como os de Daisy Cocco de Fillipis e Silvio Torres-Saillant, também citados por Ostman (2017), são exemplos da pujante produção acadêmica da comunidade dominicano-americana na atualidade. Filippis e Torres-Saillant apresentam ainda uma marcante obra ensaística bilíngue que tem como tema central a dominicanidade e as formas de ser dominicano nos Estados Unidos.

No ensaio "Eso que llamamos nuestro hogar: reflexiones en torno a la diáspora y los libros", de Cocco De Filippis, incluído na antologia Voces de Ultramar: literatura dominicana de la diáspora (Acosta; Gutiérrez, 2005), a autora descreve sua experiência pessoal de migração e as dificuldades encontradas em seus primeiros anos nos Estados Unidos ao mesmo tempo em que associa essa experiência a sua formação enquanto leitora e intelectual. Uma trajetória que apresenta muitos pontos em comum com contos e romances diaspóricos que tratam dessas questóes em uma perspectiva ficcional.

$\mathrm{Na}$ mesma antologia encontra-se "La clandestinidad cultural", ensaio de Torres-Saillant, em que o autor reflete sobre o sentimento de rechaço aos elementos culturais dominicanos cultivados por sujeitos diaspóricos que tentam se afastar o máximo possível de tudo o que possa identificá-los com 
a terra natal. Trata-se de um texto breve, mas que evidencia a necessidade de desconstrução de determinados paradigmas de valorização de elementos tidos como mais civilizados, por sua associação com países desenvolvidos, abordando a dominicanidade de um ângulo bastante distinto do escolhido por Cocco De Filippis, mas não menos representativo.

Dessa forma, os textos literários dominicanos produzidos em território norte-americano são objetos altamente complexos e densos; exemplificam, com bastante propriedade, o que Sherry Simon $(2004,14)$ descreve como "texto híbrido", ou seja, um objeto literário que resulta:

da situação de fronteira vivida pelo escritor, que consciente da multiplicidade, opta por criar um texto crioulizado, segundo a expressão de Édouard Glissant, ou seja, um texto em que a confrontação dos elementos díspares produz o novo, o imprevisível.

Merece destaque nesse sentido a emergência de revistas com esse perfil que circularam principalmente nos anos 1980 e 1990 e que se dedicavam especialmente a promover a circulaçáo de poesia dominicano-americana (Luis, 2006): Letras e imágenes (1981-1982), Inquietudes (1981-1982), Punto 7 Review (1985-1996) e Alcance (1983-1998).

Também foram publicadas nesse período antologias dedicadas a reunir textos poéticos da diáspora dominicana, dentre as quais merecem destaque Voces del exilio (1986) e Poemas del exilio y otras inquietudes (1988), organizada por Daisy Cocco de Filippis e Emma Jane Robinett, também citadas por Luis (2006). 
Nesse contexto, a cidade de Nova Iorque merece destaque como espaço fundamental para a literatura elaborada não só pela comunidade dominicana como também pela hispano-caribenha de forma geral. O imaginário dessa grande metrópole perpassa desde obras do século XIX vinculadas aos processos de independência até textos da literatura contemporânea, tanto poesia quanto prosa, das cartas escritas por Pedro Henriques Ureña em um período próximo da primeira invasão norte-americana à República Dominicana aos textos de Josefina Báez, publicados na última década, para utilizar os exemplos fornecidos por Méndez (2008). A também poeta Julia Alvarez é um dos primeiros nomes a ganhar destaque na prosa da diáspora dominicana. Nascida em 1950 em Nova Iorque, a escritora passou boa parte de sua infância na República Dominicana, retornando aos Estados Unidos em 1960, quando seus pais fizeram uma segunda tentativa de migração, ambas as mudanças motivadas por acontecimentos políticos. Embora possua uma considerável produção poética e alguns livros de não ficçâo, além de narrativas infantis e infantojuvenis, é mais conhecida por seus romances How the Garcia girls lost their accents (1991) e In the time of the butterflies (1994), ambos marcados pela experiência diaspórica e representantes da tradição literária dominicana que lida com o trauma do trujillato.

O nome de maior destaque nesse cenário, no entanto, é Junot Díaz. Um pouco mais jovem que Alvarez, Díaz foi o segundo latino a receber o prêmio Pulitzer, e sua curta obra, formada pelos volumes de contos Drown e This is how you lose here pelo romance The brief and wondrous life of 
Oscar Wao, tem recebido grande atençáo, tanto do público leitor quanto da crítica especializada.

Em uma visita rápida a livrarias norte-americanas, é possível observar o surgimento de novos autores dominicano-americanos, é o caso de escritoras como Loida Maritza Pérez, Angie Cruz, Nelly Rosario e Josefina Báez, nascidas nos anos 1960 e 1970, nomes que publicaram nas últimas décadas textos marcados pela experiência do trânsito e pela ambiguidade espacial que experimenta o migrante que vivencia frequentes retornos à terra de origem.

É importante pensar também os espaçoseditoriais ocupados por escritores com esse perfil na atualidade. Se nomes de maior reconhecimento como Díaz e Julia Álvarez publicam em grandes casas editoriais internacionais, a maior parte dos escritores dominicano-americanos se insere em editoras de pequeno e médio porte com sede em Santo Domingo ou Nova Iorque, como as mencionadas por Aponte e Gutiérrez (2013): Obsidiana Press, Cayena Publications, Ediciones Alcance, Editorial Sitel, Ediciones CEDEE, Ediciones Calíope, Ediciones del Comisionado, Ediciones Moria, Ediciones Zompopos, Editora Guanapé, Editorial Ecce Búho, Editorial Mambrú, Editorial Punto 7, La Maga Press, Morris Publishing e Urpi Editoras.

Cresceram significativamente também as publicaçóes críticas dedicadas à literatura da diáspora dominicana em específico. Merecem destaque, nesse sentido, o já citado volume Autores dominicanos de la diáspora, de Acosta e Gutiérrez (2013), como também títulos como La novela dominicana 
en Nueva York, de Héctor Amarante, publicado em 1998; La literatura dominicana al final delsiglo: diálogo entre la tierra natal y la diáspora, de Daisy Cocco de Fillipis, do ano 2000; Literatura dominicana en los Estados Unidos, historia y trayectoria de la diáspora intelectual", publicado por Franklin Gutiérrez em 2004, entre vários outros títulos.

Para caracterizar a literatura dominicano-americana na atualidade é importante também citar as diversas antologias que reúnem escritores diaspóricos. Uma lista não exaustiva inclui títulos como Voces de Ultramar (2005), que comporta poesia, prosa, ensaio e textos teatrais, organizada por Gutiérrez e Acosta; Máscaras errantes: antologia de dramaturgos dominicanos en los Estados Unidos (2011), organizada por Camen Dinorah Coronado; Desde la diáspora. Cuentos y poemas de niños y niñas dominicanos/From the diaspora, anthology of dominican children's writings, organizada por Henández et al em 2005; Nostalgias de la arena: antología de escritores de las comunidades dominicanas en los Estados Unidos, de 2011. De fato, as antologias desempenham um importante papel no estabelecimento de cânones literários. Ao mesmo tempo, são publicações que facilitam a circulação de nomes não consagrados e que ainda estáo em busca de espaço, assim como as revistas e suplementos literários.

Ainda sobre o estudo da literatura dominicano-americana, cabe citar o Instituto de Estudos Dominicanos, vinculado à Universidade da Cidade de Nova Iorque (Cuny), o único do gênero no país, que conta com uma biblioteca especializada na área e promove diversos eventos que envolvem 
a comunidade dominicana nos Estados Unidos em diversas áreas do conhecimento.

\section{CONSIDERAÇÕES FINAIS}

Em comum, os autores aqui mencionados parecem partilhar um questionamento apresentado por Méndez $(2008,3)$ :

How to conciliate an ethnic, racial, class and national identity in the United States that simultaneously draws on traits of cultural and racial multiplicity in the Dominican Republic while contending with the multi-ethnic and multiracial communities that they encounter in their new local contexts?

Cada livro parece responder à sua maneira a essa nada simples pergunta evidenciando assim o potencial criativo dos contatos efetuados no contexto da diáspora dominicana. Assim, a literatura da diáspora dominicana nos Estados Unidos parte das tensóes relacionadas ao movimento migratório em si para lidar com questóes étnicas, culturais e raciais. De fato, trata-se de uma produção ainda bastante reduzida se comparada com as literaturas cubano-americana ou porto-riquenha da diáspora, já bastante mais consolidadas enquanto campos de estudo.

$\mathrm{O}$ recente destaque dado à obra de Junot Díaz tanto em espaços acadêmicos quanto na mídia que trata de objetos culturais, no entanto, parece contribuir para o crescimento do interesse nas obras de autores dominicano-americanos. Acredito, dessa forma, que existe uma tendência de crescimento da atenção tanto do público quanto da crítica para essa 
produção literária, especialmente para a narrativa, que parece ser o gênero que mais vem ganhando destaque nesse sentido.

Dessa forma, cabe à crítica fazer também um deslocamento no sentido de aproximar a produção literária com perfil diaspórico tanto da literatura do país de origem quanto das produçôes do país receptor. Como o sujeito transnacional que tem a dualidade como marca principal, essa literatura também deve ser observada para além da organização tradicional dos Estados nacionais.

O presente trabalho, longe de esgotar essa produção literária tão jovem quanto interessante, procurou apresentar um breve panorama da literatura dominicana produzida nos Estados Unidos. Acredito que exercícios como esse, ainda que bastante tímidos, sejam importantes passos para a inclusão do estudo das literaturas diaspóricas no campo mais amplo das literaturas latino-americanas. De fato, para pensar o literário na contemporaneidade é cada vez mais importante cruzar fronteiras.

\section{REFERÊNCIAS BIBLIOGRÁFICAS}

Acosta, José; Gutiérrez, Franklin. Voces de Ultramar: literatura dominicana de la diáspora. Santo Domingo: Dirección General de la Feria del Libro, 2005.

Aponte, Sarah; Gutiérrez, Franklin. Autores dominicanos de la diáspora: apuntes bibliográficos (1902-2012). Santo Domingo: Biblioteca Nacional, 2013.

Barquet, Jesús; (2011). Reflexiones sobre la literatura hispana en los Estados Unidos. In: Anales del Coloquio Internacional Identidades culturales y presencia latina en los Estados unidos. Casa de las Américas: Habana, 2011.

Brah, Avtar. Cartografías de la diáspora: identidades en cuestión. Madrid: Traficantes de Sueños, 2011. 
Clifford, James. "Diasporas". In: Cultural Anthropology, 9-3, 1994, 302-338. Disponível em: https://bit.ly/2xw1KuQ. Acesso em 2 mar. 2014.

Cocco de Fillipis, Daisy. La Literatura dominicana al final del siglo: diálogo entre la tierra natal y la diáspora. CUNY Dominican Studies Institute: Nova Iorque, 1999.

Cocco de Fillipis, Daisy; Gutiérrez, Franklin. Literatura dominicana en los Estados Unidos: presencia temprana. Santo Domingo: Editora Búho, 2001.

Duany, Jorge. "Las diásporas de las antillas hispánicas: una comparación transnacional”. In: Revista del CESLA, 1-13, 2010, 265-286. Disponível em: https://bit.ly/31nVgIr. Acesso em 12 dez. 2015.

Duany, Jorge. "La nación en la diáspora: las múltiples repercusiones de la emigración puertorriqueña a Estados Unidos". In: Revista de Ciencias Sociales, 17, 2007, 118 153. Disponível em: https://bit.ly/2yCYGLc. Acessoem 12 dez. 2015.

Duany, Jorge. Quisqueya on the Hudson: the transnational identity of dominicans in Washington Heights. Nova Iorque: CUNY Dominican Studies Institute, 2008. Disponível em: https://bit.ly/2MHtouL. Acessoem 30 set. 2017.

Flores, Juan. The Diaspora Strikes Back: "Caribeño" Tales of Learning and Turning, Routledge, New York, 2008.

Hall, Stuart. Da Diáspora. Identidades e Mediaçóes Culturais. Belo Horizonte: Ed. UFMG/ Brasília: Representação da Unesco no Brasil, 2008.

Itzigsohn, José; Cabral, Carlos Dore; Hernández Medina, Esther; Vázquez, Obed. "Mapping dominican transnationalism: narrow and broad transnational practices", Ethnic and Racial Studies, 22-2, 1999, 316-339.

Luis, William. "Literatura latino-americana (hispano-caribeña) escrita en los Estados Unidos”. In: Echevarría, Roberto González; Pupo-Walker, Enrique (orgs.). Historia de la literatura hispanoamericana II, El siglo XX. Madrid: Gredos, 2006, 526-556. 
Méndez, Danny. In zones of contact (combat): dominican narratives of migration and displacements in the United States and Puerto Rico. Dissertação de Doctor of Philosophy. The University of Texas, Austin: 2008.

Ostman, Heather. The fiction of Junot Diaz: reframing the lens. Maryland: Rowman\& Littlefield, 2017.

Mateo Palmer, Margarita. "La literatura caribeña al cierre del siglo". In: Revista Iberoamericana, LIX-164-165, 1993, 605-626. Disponível em: https://bit. ly/2ODnRIr. Acesso em 7 dez. 2015.

Palmero González, Elena. "Deslocamento/desplaçamento". In: Bernd, Zilá. Dicionário das mobilidades culturais: percursos americanos. Porto Alegre: Literalis, 2010.

Ramirez, Luz Elena. Encyclopedia of Hispanic-american Literature. Nova Iorque: factson file, 2008.

Simon, Sherry. Hibridações culturais, Hibridações textuais. In PORTO, Maria Bernadette Velloso. Identidades em Trânsito. 1ed.Niterói: EdUFF/ABECAN, 2004, v. 1, p. 13-24.

Torres-Saillant, Silvio. "Before Diaspora: early Dominican Literature in the United States". In: Herrera-Sobek, María; Korrol, Virginia Sánchez (ed.). Recovering the U.S. hispanic literary heritage. Houston: Arte Público Press, 2000, 35-39.

Venutti Lawrence. The translator's invisibility: a History of translation. Nova Iorque: Routledge, 2008. 